\title{
Economic valuation for tembawang ecosystem, in Sanggau District, West Kalimantan, Indonesia
}

\author{
EMI ROSLINDA", SITI MASITOH KARTIKAWATI, RABUDIN \\ Faculty of Forestry, Universitas Tanjungpura. Jl. Imam Bonjol, Pontianak 78124, West Kalimantan, Indonesia. Tel.: +62-561-765342, 583865, 732500, \\ Fax.: +62-561-765342. `email: eroslinda71@gmail.com
}

Manuscript received: 5 April 2017. Revision accepted: 29 September 2017.

\begin{abstract}
Roslinda E, Kartikawati SM, Rabudin. 2017. Economic valuation for tembawang ecosystem, in Sanggau District, West Kalimantan, Indonesia. Biodiversitas 18: 1506-1516. The tembawang ecosystem in West Kalimantan (Indonesia) spreads over especially in Sanggau District region. Tembawang is a system of land used by customary community of Dayak ethnic which is traditionally managed and communally used. The objective of this study is to determine the total economic value (TEV) of the tembawang ecosystem. Survey methods were used in this research. 70 respondents were selected by census method. Total economic values in this research were restricted on direct use value, indirect use value and option value. Based on market price (biomass) and opportunity cost (hydrological role), the economic values were calculated. The results showed that total economic value of Tembawang Ampar was IDR 263,837,082 year ${ }^{-1}$, which was equivalent to IDR 36,900,291 year ${ }^{-1} \mathrm{ha}^{-1}$. They are IDR 33,545,791 year ${ }^{-1} \mathrm{ha}^{-1} \mathrm{from} \mathrm{direct}^{-1}$ use value, IDR 3,072,738 year ${ }^{-1} \mathrm{ha}^{-1}$ from indirect use value, and IDR 281,762 year $^{-1} \mathrm{ha}^{-1}$ from option value. Total economic value of tembawang was rather low. The low of economic value was due to limited benefits assessed in this study. Whereas in fact, there were many benefits from tembawang obtained by the community. Conserving tembawang ecosystem will not be achieved by simply considering the conservation of species in tembawang, but the preservation will need to encompass a wide range of natural resources and the potential services provided by them.
\end{abstract}

Keywords: Community, conservation, economic valuation, market price, tembawang

\section{INTRODUCTION}

The tembawang ecosystem in West Kalimantan (Indonesia) spreads mostly in Sanggau District region. Based on the tembawang description, tembawang is like a forest ecosystem which supports almost all the needs of a human being through its contribution of tangible and intangible values. So far, the economic value of the tembawang is generally assessed from the value of fruit production only, while the value of the environmental services of the tembawang is not considered properly. This has resulted in the underestimation of the total value of the tembawang leading to the conversion of tembawang areas into other more tangible profitable usages, and mismanagement of them. Environmental services of tembawang have no intangible benefits which are difficult to quantify and it will give rise of externalities. According to Hartwick and Oliver (1998), public externalities occur when public goods are consumed without proper payment. To suppress these externalities, there is a need to make a valuation of tembawang values.

The economic valuation of tembawang ecosystem aims to provide the economic value of resources used based on the real value from the society's viewpoint. Economic valuation offers a more comprehensive assessment of the various goods and services produced by the ecosystem so as to contribute more in-depth information for decisionmaking in sustainable forest management (Munasinghe et al. 1993 Barbier et al. 1997; Napitupulu et al. 2012; Kildow and Gino 2014; Roslinda and Yuliantini 2014; Malik 2015).

Economics as a tool in conducting economic valuation is the science about making a choice. The economic valuation of natural resources can be defined as the study of allocation of natural resources like water, land, fish and forest (Fauzi 2004). Benefits which could be provided by natural resources to meet human needs are many, but limitations in science and technology, as well as rigid institutional arrangement, has impeded the types and amount of its utilization so that obtained benefits are still very low (Darusman 2012). To make choices of several alternatives on environment management are more complex than the selection of options in the context of purely private goods (Harahap 2010). The economic valuation can be defined as the attempt to assign quantitative values to the goods and services provided by the ecosystem. The economic value of any goods or services is generally measured in terms of what we are willing to pay for the commodity less than what it costs to supply it. The objective of the valuation of ecosystem services is to indicate generally the overall economic efficiency of various uses of functions of a particular ecosystem. The underlying assumption is that ecosystem resources should be allocated to those users that yield an overall net gain to the society, as measured through valuation regarding the economic benefit of each use adjusted by its costs (Kumar and Kumar 2008). 
In the context of deciding alternative for tembawang ecosystem based on the benefit-cost rule, the decision can be justified if net benefit of ecosystem development is greater than net benefits obtained from conservation. In this case, conservation benefits are measured based on the total economic value of the tembawang ecosystem. Tembawang ecosystem in Ampar Subvillage of West Kalimantan, Indonesia has very important and significant value for the local community, i.e. social, economic and ecology. Tembawang ecosystem has multiple roles for people community and provides other benefits to the nature in maintaining forest structure, diversity, and large carbon stocking in standing biomass (Astiani and Ripin 2016). However, the existence of tembawang ecosystem often became a matter of debate by various parties whether to maintain it in current condition or to convert it into plantation palm area or other uses. The most optimal management option is not known yet as there is a lack of information on the values (benefits and function) of tembawang. Therefore, a study about the total economic value of the tembawang ecosystem is needed. The objective of this study is to determine the total economic value (TEV) of the tembawang ecosystem.

\section{MATERIALS AND METHODS}

\section{Study area}

The study was done on September 2014 until February 2015. The area of research was in Tembawang Ampar in Ampar Subvillage (dusun), Cempedak Village (desa), Tayan Hilir Subdistrict, Sanggau District in West Kalimantan, Indonesia which was located in $00^{\circ} 43^{\prime} 06^{\prime \prime} \mathrm{LU}$ and $110^{\circ} 18,5^{\prime} 39^{\prime \prime}$ BT (Figure 1). Ampar Subvillage is situated along the trans-Kalimantan interstate highway and can be reached by car and a motorcycle. Based on the Schmidt and Ferguson classification, climate type of Ampar Subvillage area is classified into the type A (very wet) with mean temperature of $29^{\circ} \mathrm{C}$ and the average rainfall between 3,000-4,000 $\mathrm{mm}$ per year. Ampar Subvillage topography consists of a flat, wavy to hilly with slope level of $0-30 \%$ and is located at an altitude of 24-140 $\mathrm{m}$ above sea level. The soil type is dominated by redyellow podzolic. Tembawang Ampar covers \pm 6,69 ha (Ripin 2014). Some parts of it are still covered by forest, but most of it has been deforested and converted to community plantation (palm and rubber) and stone quarries.

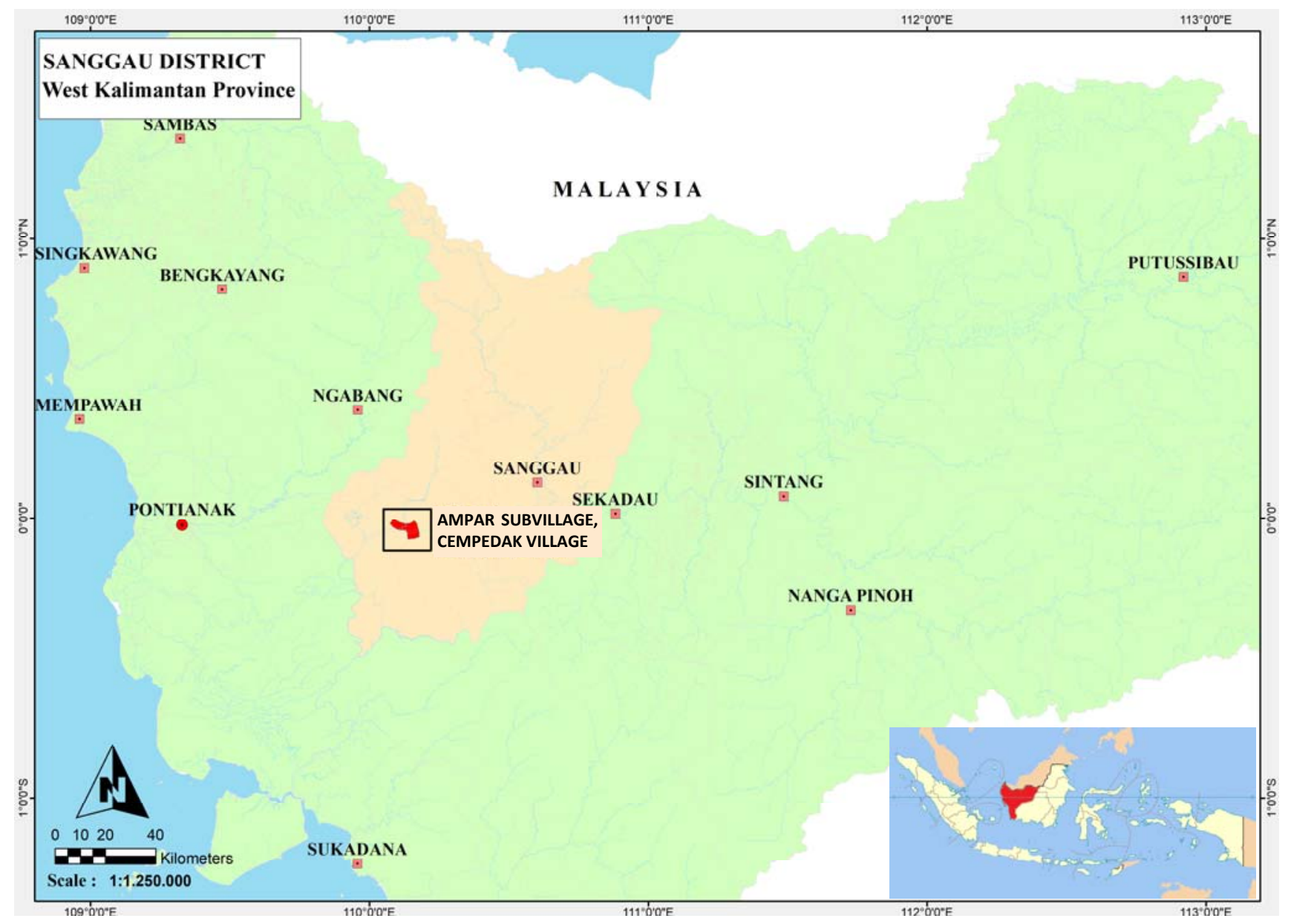

Figure 1. Site location in Ampar Subvillage, Cempedak Village, Tayan Hilir Subdistrict, Sanggau District, West Kalimantan, Indonesia 
The dominant ethnic of the community is Dayak Tobak. They still adhere to the customs and culture from their ancient ancestors. The community is led by a tribal chief which plays a very important role. The roles of the chief at Tayan Hilir Sub-district are (i) the Domong Adat, a tiered traditional judiciary; and (ii) the Custom Judge, the one who listen to the customary cases at the village level. 'Opeope' is local language of Ampar people for daily internal interaction, and Indonesian language is used to interact with people from outside community. The majority of them are Catholic.

The level of education of people in Ampar Subvillage is relatively low. It can be seen from the percentage of people who did not graduate or only graduated from elementary school, that is $70 \%$. The number of people who are studying in junior high and high school is about $28.4 \%$. And only $1.6 \%$ of them have graduated from D3 or S1 (Pemdes Cempedak 2014). Most of the community lives from farming such as rice planting (berhuma) on the wetpaddy field (sawah) and upland farming (leading). Planting and cultivating rubbers is a source of income for them. The rest of community works as traders or as employees of road construction company, PT. Strada Multiperkasa Company, which was operating in those sub-villages at that time.

\section{Data collection}

The research was conducted by using survey aiming to collect data from a number of people through interviews, field observation, and literature review. Seventy people were selected by some considerations through census method. Ampar Subvillage is inhabited by 70 households with a total population of 350 people, which consists of 200 men and 150 women (Pemdes Cempedak 2014014). Selection of sample village was done purposively based on tembawang ecosystem existing in the villages. While respondents selected are members of Ampar Subvillage and the people who directly or indirectly got its benefits. Some questions asked to respondents include the kind of products and services they attained, the money they procured and the frequency of the procurement, and the consideration of the importance and the value of the existing tembawang. Secondary data were obtained from the literature, reports and other documents related to the study.

\section{Identify types of tembawang use}

Tembawang benefits were analyzed descriptively including type, location, scale, system and model of utilization. Analysis of total economic value of tembawang was conducted using formula from Munasinghe (1993), namely, as follows:

$$
\begin{aligned}
& \text { TEV = (DUV +IUV +OV })+(\mathrm{XV}) \\
& \text { Where: } \\
& \text { TEV = Total economic value } \\
& \text { DUV = Direct use value } \\
& \text { IUV = Indirect use value } \\
& \mathrm{OV}=\text { Option value } \\
& \mathrm{XV}=\text { Existence value }
\end{aligned}
$$

Direct use value (DUV). The immediate benefits are the benefits derived from land use of tembawang based on market prices including timber and firewood, and the benefits from its biological condition and cultivation (fruits, rubber, apik, bamboo, medicine, and animal).

Indirect use value (IUV). Indirect use value is the sum of indirect benefits gained from tembawang ecosystem including soil protection, water supply, $\mathrm{CO}_{2}$ fixation, nutrient cycling, pollutant decomposition and disease and pest control. In this research, indirect benefits are limited to its function as a water supply for domestic use. Estimation of water for domestic use was approached from water consumption costs based on standard needs of average household issued by Ampar Subvillage people.

Option value (OV). Option value is a benefit to preserve the use of goods, services and environmental resources in the future that cannot be used at present. In this research, the value to be used is the benefit of some fruits that are not used at the current time. Option value benefit was approached by market price.

Existence value (XV). Existence value is a benefit perceived by the public from the presence of tembawang ecosystem after other benefits (direct benefits, indirect benefits, and option value) are removed from the analysis. It is benefit to be enjoyed by human from the existence of tembawang ecosystem. In this research, existence value is not being calculated.

The total economic value of this research is derived from direct use value, indirect use value and option value. Direct use value and option value were categorized as intangible products, and indirect use value was categorized as intangible product. The tangible and intangible products of the tembawang were grouped into biomass and hydrological role (see Figure 2).

The economic values were calculated based on market price (biomass), opportunity cost (hydrological role) and contingent valuation method (Munasinghe 1993). Market price method uses the prices of goods and services bought and sold on the commercial market to determine the value of an ecosystem service. This method only measures values and marketed goods or services having an actual price. The following formula is used for calculating the Total Economic Value: TEV = DUV + IUV + OV.

\section{RESULTS AND DISCUSSION}

\section{Respondent profile}

Seventy respondents were interviewed using census. The respondents' ages are 25-77 years old and reside at Ampar Subvillages (dusun). Among the respondents, only five are female. Furthermore, all respondents are Catholic and most of them did not complete the elementary school. This was because the educational facilities in the Ampar Subvillage were still very limited from the past time until now. Most of the respondents are farmers. The respondents' profile can be seen in Table 1. 


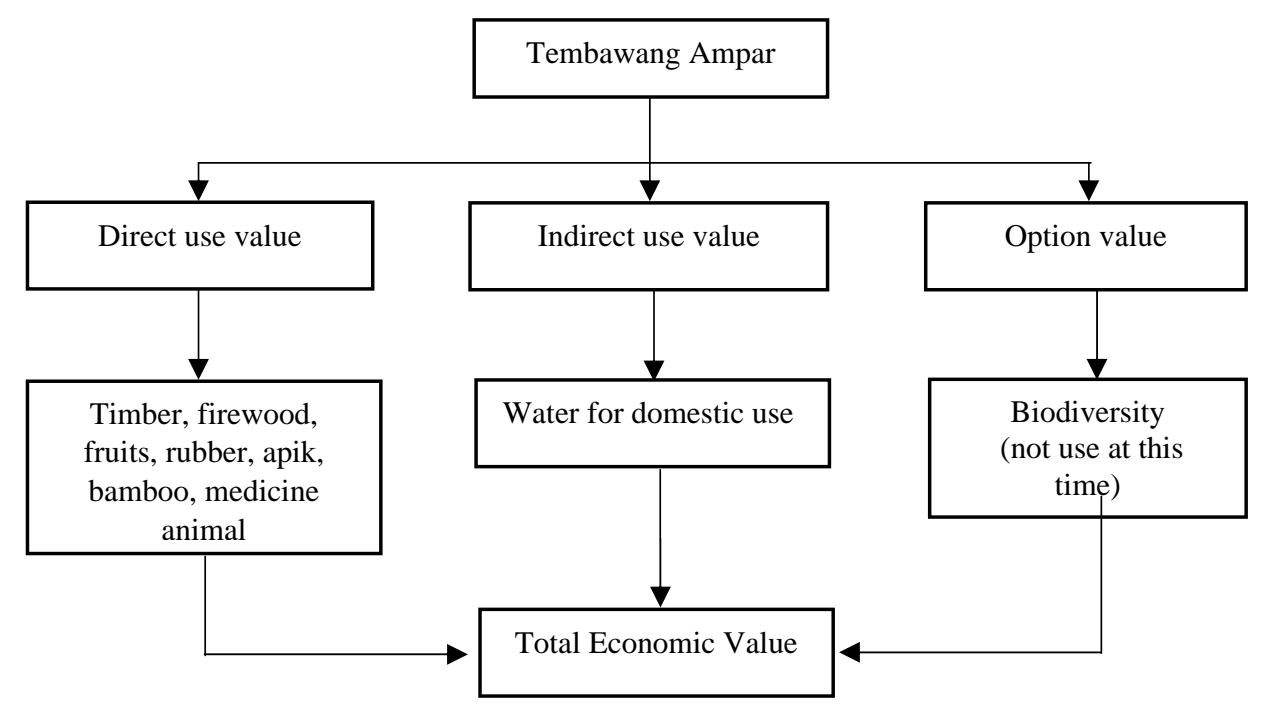

Figure 2. Total Economic Value of Tembawang Ampar in Ampar Subvillage, Cempedak Village, Tayan Hilir, Sanggau District, West Kalimantan, Indonesia

Table 1. Respondent profile

\begin{tabular}{|c|c|c|c|}
\hline Profile & Category & Number & $(\%)$ \\
\hline \multirow[t]{3}{*}{ Gender } & Female & 5 & 7.14 \\
\hline & Male & 65 & 92.86 \\
\hline & Amount & 70 & 100.00 \\
\hline \multirow[t]{6}{*}{ Age } & $25-35$ & 22 & 31.42 \\
\hline & $36-45$ & 19 & 27.14 \\
\hline & $46-55$ & 19 & 27.14 \\
\hline & $56-65$ & 8 & 11.42 \\
\hline & $66-77$ & 2 & 2.86 \\
\hline & Amount & 70 & 100.00 \\
\hline \multirow[t]{5}{*}{ Religion } & Moslem & 4 & 5.71 \\
\hline & Christian & 10 & 14.28 \\
\hline & Catholic & 55 & 78.57 \\
\hline & Buddhism & 1 & 1.42 \\
\hline & Amount & 70 & 100.00 \\
\hline \multirow[t]{4}{*}{ Education } & $\begin{array}{l}\text { Elementary School or } \\
\text { below }\end{array}$ & 57 & 81.43 \\
\hline & Junior High School & 8 & 11.43 \\
\hline & Senior High School & 5 & 7.14 \\
\hline & Amount & 70 & 100.00 \\
\hline
\end{tabular}

All respondents stated that their main livelihood is farming, such as rice planting (berhuma), both on the wetpaddy field (sawah) or on the upland farm (ladang). Rice planted on paya and mongo were harvested once a year. The yields of rice from 1 ha of paya and mongo are approximately $200 \mathrm{~kg}$ and $400 \mathrm{~kg}$, respectively. The rice production is for subsistence.

All respondents have a rubber plantation. Rubber tapping is a second job even though it is economically profitable than farming. This activity is performed routinely in the morning before going to the upland farm, when the trees produce a lot of latex. The latex can be tapped approximately $5 \mathrm{~kg}$ per day. The latex is usually collected first and then sold to a middleman at a price of approximately IDR 6,000 per $\mathrm{kg}^{-1}$. The result from rubber tapping is enough to cover the family needs. Besides rubber, oil palm is one of the commercial crops they choose to be planted. Figure 3 shows the agricultural lands of Dayak Tobak community.

\section{Tembawang ecosystem}

Tembawang is a system of land use by the customary community of Dayak ethnic in West Kalimantan which is traditionally managed and used communally. Tembawang is often referred to as an agroforestry because it has a variety of plants ranging from trees with a diameter over $100 \mathrm{~cm}$ to understory plants. Tembawang is regarded as a unique ecosystem for storing high values in terms of biodiversity, economic, and conservation moral.

Tembawang has a strong relationship with the shifting cultivation which has been practiced since hundreds of years ago. In the past, the Dayak settlements moved to follow the movement of their upland farm location. They usually grew various kinds of fruits, crops, and spices in their settlement location. When they moved, the location of the old settlement will be abandoned and become an agroforestry which is then called tembawang.

Tembawang Ampar has formed hundreds of years ago (Figure 4). Tembawang Ampar has already come into the seventh generations. Based on land ownership (land tenure), Tembawang Ampar is communal property owned by several families that are bound in a big family. They own tembawang as an inheritance from their parents or ancestors. 


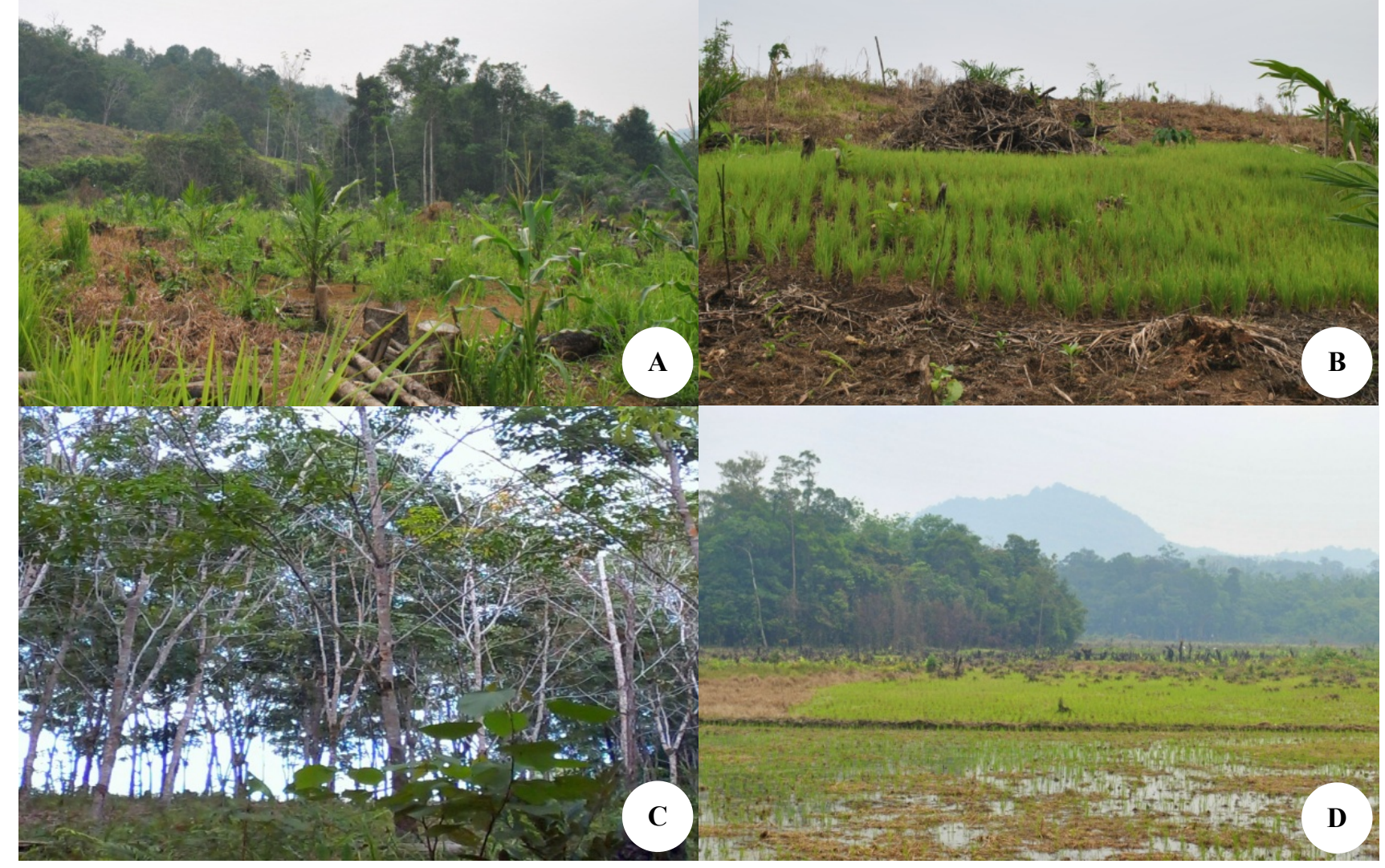

Figure 3. Source of income for respondents in Ampar Subvillage, West Kalimantan, Indonesia. A. Rice planting (berhuma) on the upland farm (ladang), B. Planting rice on the wet-paddy field (sawah), C. Planting commercial crops, rubber tree, D. Planting oil palm

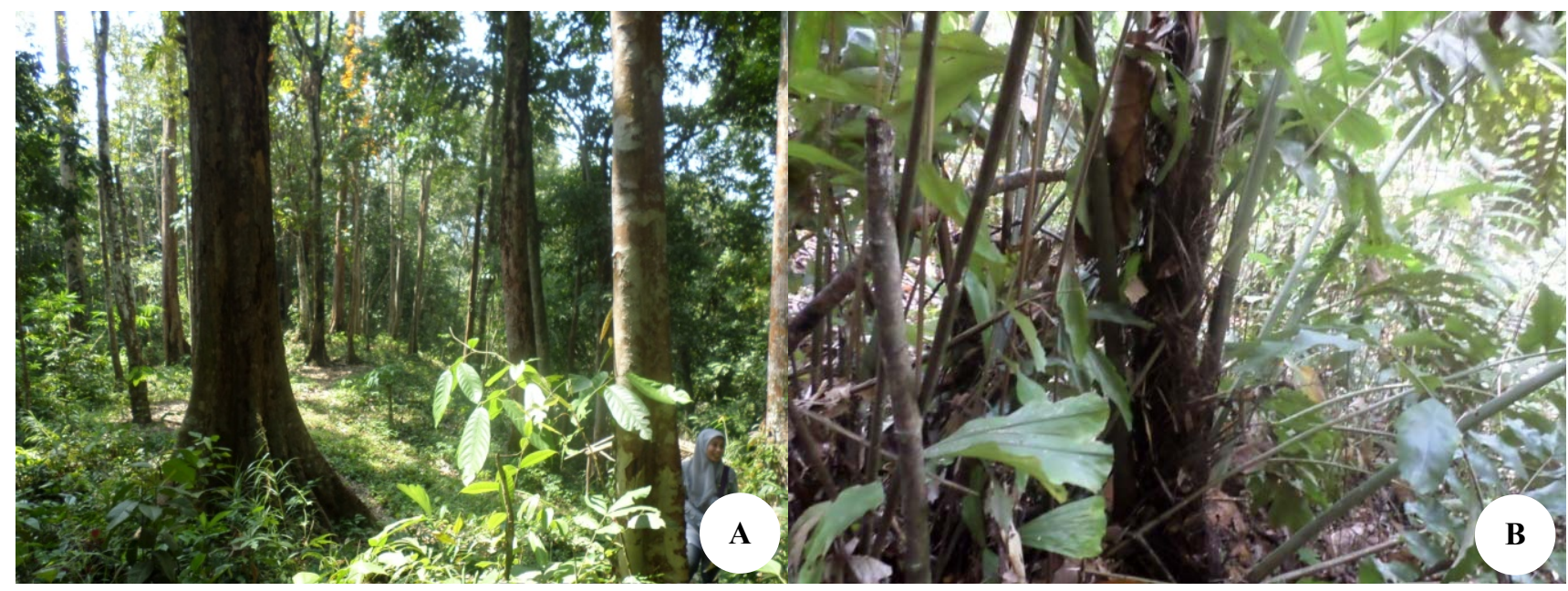

Figure 4. The figure of Tembawang Ampar of West Kalimantan, Indonesia. A. Fruit trees, B. Apik (Arenga undulatifolia Becc.)

In Tembawang Ampar, there are 84 plant species which are utilized by Dayak community. Most of them are fruit tree species. Meanwhile, based on Ripin (2014), there were 97 plant species from 37 families found in the tembawang. Furthermore, Astiani and Ripin (2016) stated that, in Tembawang Ampar, each land cover type was dominated by almost similar species such as karet, mahang, and durian. Tembawang Ampar was dominated with durian (Durio zibethinus Murr), rambutan (Nephelium lappaceum L.), duku (Lansium domesticum Corr var. duku), mahang (Macaranga pruinosa Muell. Arg), karet (Hevea brasilliensis Will ex A. Juss), asam gandaria (Bouea macrophylla Griff.), asam kemantan (Mangifera torquenda Kosterm.), jengkol (Archidendron pauciflorum (Benth.) 
I.C.Nielsen), engkasai (Pometia glabra (BI) Teijsm.), and apik (Arenga undulatifolia Becc.). The apik was naturally grown plant on the hilly site which was found abundant and grew among the fruit trees. In Tembawang Ampar, the main characteristic of tembawang is durian (Durio zibethinus). High economic value is the major reason that made durian as the main crop in tembawang. Durian fruit harvest is performed one to two times a year, the great harvest (panen raya) period is in August and the end of harvest (panen ujung buah) period is in February. Fruits that are obtained at the end of the fruit harvest period are not as many as in August. Fruit tree species found in Tembawang Ampar can be seen in Table 2 and Figure 3.

Table 2. Fruit tree species found in Tembawang Ampar

\begin{tabular}{|c|c|c|}
\hline Vernacular name & Scientific name & Family \\
\hline Ambacang & Mangifera swintoniodes Kosterm & Anacardiaceae \\
\hline Asam gandaria & Bouea macrophylla Griff. & Anacardiaceae \\
\hline Asam kemantan & Mangifera torquenda Kosterm. & Anacardiaceae \\
\hline Asam mawang & Xanthophyllum excelsum Miq. & Anacardiaceae \\
\hline Belimbing darah & Baccaurea angulata Merr. & Euphorbiaceae \\
\hline Cempedak & Artocarpus teysmanni Miq. & Moraceae \\
\hline Cempedak air & Artocarpus champeden (Lour.) Stokes & Moraceae \\
\hline Ceriak & Baccaurea sp. & Euphorbiaceae \\
\hline Duku & Lansium domesticum Corr var. duku & Meliaceae \\
\hline Durian & Durio zibethinus Murr. & Bombacaceae \\
\hline Emponat & Litsea sp. & Lauraceae \\
\hline Engkasai & Pometia glabra (Bl.) Teijsm. & Sapindaceae \\
\hline Engkubu & Nephelium sp. & Sapindaceae \\
\hline Kapul & Baccaurea bracteata Müll. Arg. & Euphorbiaceae \\
\hline Kedondong hutan & Canarium sp. & Burseraceae \\
\hline Kelampai tupai & Blumeodendron tokbrai $\mathrm{Bl}$. & Euphorbiaceae \\
\hline Kelampai & Elateriospermum tapos Bl. & Euphorbiaceae \\
\hline Kelawik/teratungan & Durio oxleyanus Griff. & Malvaceae \\
\hline Ketup & Lansium domesticum Corr. var. aquaeum & Meliaceae \\
\hline Kubing & Artocarpus heterophyllus Lam. & Moraceae \\
\hline Kumpang & Gynnacranthera forbesii Warb. & Burseraceae \\
\hline Langsat & Lansium parasiticum (Osbeck) K.C.Sahni \& Bennet & Meliaceae \\
\hline Manggis & Garcinia mangostana L. & Guttiferae \\
\hline Mentawa & Artocarpus anisopyllus Miq. & Moraceae \\
\hline Nangka & Artocarpus heterophyllus Lam & Moraceae \\
\hline Peluntan & Artocarpus rigidus $\mathrm{Bl}$. & Moraceae \\
\hline Pingan & Artocarpus odoratissimus Blanco & Moraceae \\
\hline Porik & Nephelium sp. & Sapindaceae \\
\hline Rambai & Baccaurea motleyana Muell. Arg. & Euphorbiaceae \\
\hline Rambutan & Nephelium lappaceum L. & Sapindaceae \\
\hline Salak & Salacca edulis Reinw. & Arecaceae \\
\hline Sibau & Nephelium uncinatum Radlk. ex Leenh. & Sapindaceae \\
\hline Sotol/kecapi & Sandoricum koetjape (Burm. F.) Merr & Meliaceae \\
\hline Sukun & Artocarpus altilis (Park.) Fosberg & Moraceae \\
\hline Tampoi & Baccaurea grifithii Hookf. & Euphorbiaceae \\
\hline
\end{tabular}

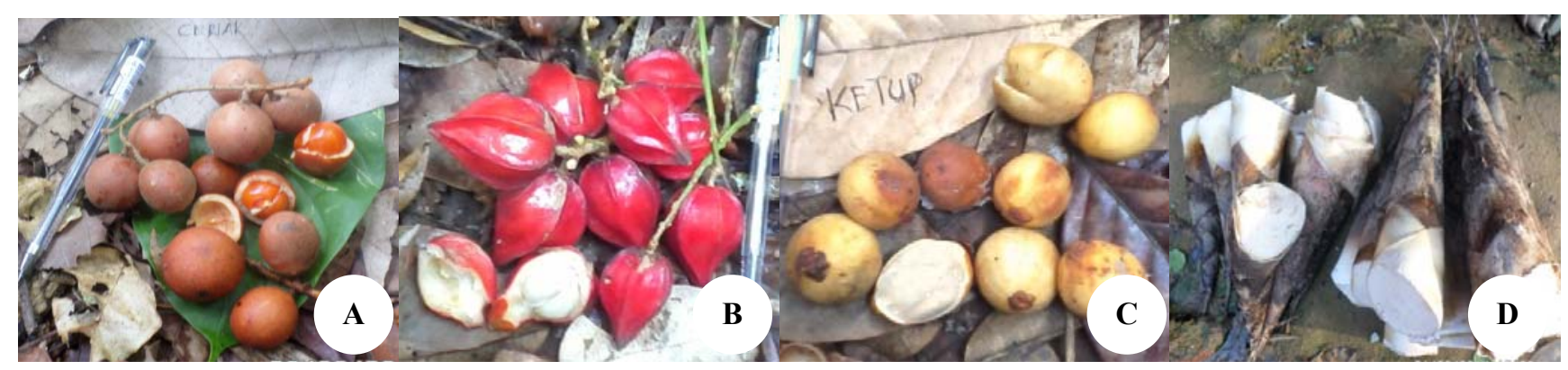

Figure 4. The figure of: A. Ceriak (Baccaurea sp.), B. Belimbing darah (Baccaurea angulata Merr.), C. Ketup (Lansium domesticum var. aquaeum.), D. Apik (Arenga undulatifolia Becc.) 


\section{Identification of tembawang ecosystem benefits in Ampar Subvillage}

By understanding the value, those involving goods and services produced by a natural resource and the environment can be found particularly different. It depends on the view angle used by the scientist. The difference on the concept of value can make difficulty in understanding the importance of an ecosystem. Therefore, it is necessary to have a similar perception of the ecosystem assessment (Harahap 2010). Benefits of tembawang ecosystems in Ampar Subvillage consisted from direct, indirect, and option value.

\section{Total economic value (TEV) of tembawang ecosystem Direct use value}

The direct benefits of tembawang ecosystem come from the activities of producing a log, collecting firewood, collecting some fruits (usually used and have a market price), collecting apik, collecting rubber, collecting bamboo, collecting some medicinal plants and collecting animals. Tembawang Ampar provides some commercial log, i.e. Meranti batu (Shorea palembanica Miq.), meranti padi (Shorea leprosula Miq.), Tengkawang rambai (Shorea splendid (de Vr.) Ashton) Tengkawang tungkul (Shorea stenioptera Burck.). They were valued by market price based on Regulation of the Minister of Trade of the Republic of Indonesia Number 92/M-Dag/Per/10/2015 and they have to reach the level of the tree with diameter $>20$ $\mathrm{cm}$. In this research, data of wood potency used the method from Ripin research (2014). The total value of wood is IDR $67,821,402$ year $^{-1}$. Table 3 will describe the economic value of wood in Tembawang Ampar.

Although most people in Ampar Subvillage have already used oil and gas stoves, some still uses firewood as additional energy. It was found that the use of firewood from tembawang has several advantages, i.e., faster heating time and money saving. Collecting firewood is done on an area close to their settlement. The economic value of firewood was counted by a willingness to pay. Based on the interview, there were $27 \mathrm{HH}$ who still do the activity of collecting firewood in tembawang area. The value of firewood in Tembawang Ampar is IDR 1,296,000 year $^{-1}$. Table 4 describes the economic value of firewood.

Fruit trees are the dominant species in Tembawang Ampar. Therefore some researchers called it the garden of mixed fruits. There are many kinds of fruits used by the community and have their own market prices, such as durian, cempedak, langsat, duku, belimbing darah and rambai. The value of collecting some fruits $(27 \mathrm{HH})$ is IDR $108,000,000$ year $^{-1}$. Table 5 describes the economic value of some fruits.

Tembawang provides some food for the community, one of them is apik. Apik is used for the community as a vegetable for their daily food. Apik has a market price. The price of apik based on their size, the price of the larger ones is IDR 15,000 per bunch (ageh). Meanwhile, the little one is IDR 5,000 per bunch. The value benefits of collecting apik (27 HH) is IDR 540,000 per year. Table 6 describes the economic value of apik.
Rubber tapping was a common activity in Ampar Subvillage and a source of livelihood to increase the family income. Rubber has a certain market price. Although, the rubber prices continue to decline, this activity is being conducted as an alternative to community work. Collecting the rubber is done on an area close their settlement. Assuming that there are $6 \mathrm{HH}$ who are still tapping rubber in tembawang, The value of rubber tapping (6 HH) is IDR $25,920,000$ year $^{-1}$. Table 7 describes the economic value of rubber tapping.

The high potential of bamboo can be found in Tembawang Ampar since it can be found in considerable amounts. Bamboo was utilized by people to make a pole, trigai (used to pick fruits) and rebung (bamboo shoots = can be eaten as a vegetable). The value of bamboo follows market price. Assuming that, there are $27 \mathrm{HH}$ of total respondents collecting the bamboo in tembawang, so the value of bamboo is IDR 9,720,000 per year. Table 8 describes the economic value of bamboo.

The potential of medicinal plants can be found in Tembawang Ampar. Based on Zuhud et al. (2015), the use of medicinal plant species in the tembawang area can be grouped into 13 groups of diseases curement, i.e: wound, stomachache/diarrhea, body stool, toothache, swell, breath shortness, stiff, sprain, dizzy, malaria, eyesore, fever, postpartum. So far, the community usually collects medicinal plants only when they are needed. Value of medicine plants is counted by substitution price with assumption that: (i) the price of medicinal plants is assumed to be equal to the price of medicine in the market around the community, except for the price of akar kuning, (ii) there are 70 households who utilize the medicinal plants, (iii) medicinal plants are commonly used by community. So the value of medicinal plants is IDR 18.480.000 per year. Table 9 describes the economic value of medicinal plants.

Some animals often found in tembawang area are wild boar, monkeys, rabbits, hedgehogs, squirrels, munsang, pelandok and deer. The animals which are calculated their direct use values are deer (Muntiacus muntjak), pelanduk (Tragulus spp.), musang (Paradoxurus hermaphroditus), and tupai (Tupaia javanica). They are caught by hunting. Assuming that there are $5 \mathrm{HH}$ of total respondents who hunted in tembawang, so the value of the animal is IDR $8,075,00$ year $^{-1}$. Table 10 describes the economic value of the animal.

\section{Indirect use value}

An indirect benefit of tembawang function has a relation to hydrology. All the value of tembawang relating to hydrology is obtained by using market price. From field observation and interview results, people now are able to utilize water for various domestic needs in better way. The value of hydrology in tembawang is determined by water consumption for domestic use on $\mathrm{HH}$ who have to purchase it. Only $38 \mathrm{HH}$ utilized the water for consumption from Tembawang Ampar source, the rest (32 $\mathrm{HH})$ use water from the other source. The value of hydrology is IDR 21,970,080 per year. Table 11 describes the economic value of the hydrological function. 
Table 3. Economic value of log

\begin{tabular}{|c|c|c|c|c|c|}
\hline \multicolumn{3}{|l|}{ Log species } & Volume $\left(\mathbf{m}^{3}\right)$ & Price (IDR) & Amount (IDR) \\
\hline \multicolumn{3}{|c|}{ Jabon (Neolamarckia cadamba (Roxb.) Bosser) } & 4.6735 & 90,000 & 420,615 \\
\hline \multicolumn{3}{|c|}{ Meranti Batu (Shorea palembanica Miq.) } & 17.4176 & 760,000 & $52,949,443$ \\
\hline \multicolumn{3}{|c|}{ Meranti Padi (Shorea leprosula Miq.) } & 1.7097 & 730,000 & $1,248,103$ \\
\hline \multicolumn{3}{|c|}{ Tengkawang Rambai (Shorea splendida (de Vriese) P. Ashton) } & 0.4154 & 730,000 & 303,258 \\
\hline \multicolumn{3}{|c|}{ Tengkawang Tungkul (Shorea stenoptera Burck.) } & 16.9737 & 760,000 & $12,899,984$ \\
\hline \multicolumn{3}{|c|}{ Total } & & & $67,821,402$ \\
\hline \multicolumn{6}{|c|}{$\begin{array}{l}\text { Note: Price of log based on Regulation of Ministry of Trading Republik Indonesia Nomor 12/M-Dag/Per/3/2014. Assuming the price of } \\
\text { tengkawang tungkul is same with the price of other shorea. The potency of log was based on Ripin (2014) }\end{array}$} \\
\hline \multicolumn{6}{|l|}{ Table 4. Economic value of firewood } \\
\hline Item & Price (IDR) & Need & Unit & & fit value (IDR) \\
\hline Firewood & 5,000 & 4 & Bunch HH & & \\
\hline Willingness to pay & & 4,000 & Bunch HH & ear $^{-1}$ & \\
\hline Time needs for collecting firewood & & 30 & Minute bu & & \\
\hline Times of cooking & & 3 & Times day & & \\
\hline Value of firewood $27 \mathrm{HH}^{-1}$ year $^{-1}$ & & & & & 6,000 \\
\hline
\end{tabular}

Table 5. Economic value of fruits

\begin{tabular}{lccrr}
\hline Species & Price (IDR) & Product/HH & Unit & Benefit value (IDR) \\
\hline Durian (Durio zibethinus Murr.) & 10,000 & 300 & Fruit & $3,000,000$ \\
Cempedak (Artocarpus teysmanni Miq) & 3,000 & 200 & Fruit & 600,000 \\
Langsat (Lansium parasiticum (Osbeck) K.C.Sahni \& Bennet) & 5,000 & 40 & $\mathrm{~kg}$ & 200,000 \\
Duku (Lansium domesticum Corr var. duku) & 5,000 & 20 & $\mathrm{~kg}$ & 100,000 \\
Belimbing darah (Baccaurea angulata Merr.) & 5,000 & 10 & Ageh (bunch) & 50,000 \\
Rambai (Baccaurea motleyana Mull. Arg). & 5,000 & 10 & Ageh (bunch) & 50,000 \\
Value of fruits/HH/year & & & & $4,000,000$ \\
Value of fruits for 27HH/year & & & $108,000,000$ \\
\hline
\end{tabular}

Table 6. The economic value of apik

\begin{tabular}{lcccc}
\hline Component & Price/bunch (IDR) & Product/year & Unit & Benefit value (IDR) \\
\hline Apik & 10,000 & 2 & Bunch & 20,000 \\
Value of apik (27 HH) year ${ }^{-1}$ & & & & 540,000 \\
\hline
\end{tabular}

Table 7. The economic value of rubber

\begin{tabular}{|c|c|c|c|c|}
\hline Item & Price/Kg (IDR) & Product/day & Unit & Benefit value (IDR) \\
\hline Rubber & \multirow[t]{4}{*}{6.000} & \multirow[t]{4}{*}{3} & \multirow[t]{4}{*}{$\mathrm{kg}$} & 18,000 \\
\hline Value of & & & & 108,000 \\
\hline Value of & & & & $2,160,000$ \\
\hline Value of & & & & $25,920,000$ \\
\hline
\end{tabular}

Table 8. The economic value of bamboo

\begin{tabular}{|c|c|c|c|c|}
\hline Item & Price & Product/month & Unit & Benefit value (IDR) \\
\hline Pole & 2,000 & 5 & Pole & 10,000 \\
\hline Rebong & 2,000 & 10 & Ageh/ikat & 20,000 \\
\hline \multicolumn{4}{|c|}{ Value of bamboo (/HH/month) } & 30,000 \\
\hline \multicolumn{4}{|c|}{ Value of bamboo (/HH/year) } & 360,000 \\
\hline \multicolumn{4}{|c|}{ Value of bamboo (/27HH/year) } & $9,720,000$ \\
\hline
\end{tabular}


Table 9. The economic value of medicinal plants

\begin{tabular}{|c|c|c|c|c|}
\hline Medicinal plants & Price (IDR) & Product/month & Unit & Value (IDR) \\
\hline Sugi (Pleomele angustifolia Medik) & 3,000 & 2 & Pieces & 6,000 \\
\hline Akar kuning (Fibraurea tinctoria Lour) & 10,000 & 1 & Stem & 10,000 \\
\hline Pakis engkomok (Pterydophyte) & 3,000 & 1 & Pieces & 3,000 \\
\hline Bakung (Crinum asiatacum Linn.) & 3,000 & 1 & Fruit/pieces & 3,000 \\
\hline Value/HH/month & & & & 22,000 \\
\hline Value/70HH/month & & & & $1,500,000$ \\
\hline Value/70HH/year & & & & $18,480,000$ \\
\hline
\end{tabular}

Table 10. The economic value of animal

\begin{tabular}{|c|c|c|c|c|}
\hline Animal & Price (IDR) & Produts & Unit & Value (IDR) \\
\hline Kijang (Muntiacus muntjak Zimmerman) & 50,000 & $1=20$ & $\mathrm{~kg}$ & $1,000,000$ \\
\hline Pelanduk (Tragulus spp.) & 50,000 & $2=6$ & $\mathrm{~kg}$ & 300,000 \\
\hline Musang (Paradoxurus hermaphroditus Pallas) & 35,000 & $3=9$ & $\mathrm{~kg}$ & 315,000 \\
\hline Tupai (Tupaia javanica Horsfield) & 35.000 & $5=1$ & $\mathrm{~kg}$ & 35.000 \\
\hline Value HH year ${ }^{-1}$ & & & & 1.615 .000 \\
\hline Value $5 \mathrm{HH}$ year $^{-1}$ & & & & 8.075 .000 \\
\hline
\end{tabular}

Table 11. The economic value of hydrology

\begin{tabular}{|c|c|c|c|}
\hline Variable & Data & Unit & Note \\
\hline $\begin{array}{l}\text { The average of water } \\
\text { consumption/person/day }\end{array}$ & 144 & $\begin{array}{l}\text { Liter person } \\
{ }^{1} \text { day }^{-1}\end{array}$ & $\begin{array}{l}\text { Survey result from Directorate of Drinking Water } \\
\text { Development cq. Cipta Karya } 2006\end{array}$ \\
\hline $\begin{array}{l}\text { The average of water } \\
\text { consumption/household/day }\end{array}$ & 720 & $\begin{array}{l}\text { Liter day }^{-1} \\
\text { Household }^{-1}\end{array}$ & $\begin{array}{l}144 \text { x } 5 \text { (the average of household member in Ampar village } \\
\text { are } 5 \text { person }\end{array}$ \\
\hline The total water consumption/year & $9,986,400$ & $\begin{array}{l}\text { Liter year }^{-1} \\
\text { Household }^{-1}\end{array}$ & $38 \times 720 \times 365$ \\
\hline Waterer price & $\begin{array}{l}2,186 \\
2.2\end{array}$ & $\begin{array}{l}\text { IDR m } \\
\text { IDR liter }\end{array}$ & $\begin{array}{l}\text { Based on PDAM data (2011) distribution of water in Tayan } \\
\text { Hilir Sanggau sub with value of water is IDR } 135.476 .000\end{array}$ \\
\hline Value of water & $21,970,080$ & IDR year ${ }^{-1}$ & $9,986,400 \times 2,2$ \\
\hline
\end{tabular}

Table 12. Total economic value of tembawang

\begin{tabular}{lrr}
\hline Type of value & \multicolumn{1}{c}{ IDR/year } & Percentage \\
\hline Direct use value & $239,852,402$ & 90.91 \\
Indirect use value & $21,970,080$ & 8.33 \\
Option value & $2,014,600$ & 0.76 \\
Total & $263,837,082$ & 100.00 \\
\hline
\end{tabular}

\section{Option value}

Option value shows individual's willingness to pay to preserve certain natural resource for future utilization (Harahap 2010; Rachmansyah and Maryono 2010; Napitupulu 2012). Option value of tembawang was estimated by using contingent valuation method (CVM). Through this method, respondents are asked to assess the significance of the presence of tembawang ecosystems. All respondents are asked their willingness to put aside a certain amount of money. The result obtained from people's willingness to pay is IDR 2,014,600 year $^{-1}$.
Total economic value

From the analysis of potential economic value calculation, the total potential economic value of the tembawang ecosystem is IDR 263,387,082 year $^{-1}$ or IDR 36,900,291 $\mathrm{ha}^{-1} \mathrm{year}^{-1}$. Table 12 shows that the highest benefit is from direct value (90.91\%), followed by indirect value (8.33\%) and the lowest is option value $(0.76 \%)$. The research result is rather different with another research that indirect value has the highest value (Roslinda 2002; Siregar 2012; Roslinda 2013; Malik et al. 2015). It is because of the limitation of this research. Actually, tembawang ecosystem has ecological benefits. However, since most of the ecological benefits derived from tembawang ecosystems mostly cannot be acquired directly, real and close to the place they exist. Therefore, the existence of tembawang must be preserved along with the increase awareness and understanding of local community on the value and the importance of tembawang ecosystems. 


\section{Discussion}

Tembawang is one of the land uses in Dayak Toba community. Besides tembawang, in Dayak Toba land use, there were waqf land, rimba, mongo/meh, rubber plantation, oil palm plantation, paya, and jamin. Every land use has a special function and can support the community needs. This situation is similar to Dayak Desa community in Ensaid Panjang (Roslinda 2016). Tembawang was created by local knowledge and had been practiced by the communities for a very long time, so there was no difficulty to obey management of rule in utilizing tembawang. Utilization in tembawang was regulated by social norms existing in the community. One hesitating thing is that the social capital cannot guarantee the sustainability of tembawang. Tembawang can be categorized as community forestry. With strong social capital, the community forestry can be developed (Roslinda 2017).

Identification of the benefits of tembawang was performed with an analysis of the characteristics of ecosystem function that is translated into a list of goods and services (De Groot et al. 2002). The benefits of tembawang for community were material for energy (firewood), food and feed, resin, construction material, medicinal plants, material for a religious ceremony, wildlife (for hunting), hydrological function, air and climate regulation function, cultural/religious ritual, farming location, and nutrient cycling. Based on Zuhud et al. (2015, tembawang has all of those services, and the ecosystem services could provide benefits to the community because both the knowledge about the ecosystem and their services were used for subsistence of the people in the community. In addition, the Dayak Toba tradition perceives that the forests should be protected and preserved as a source of community livelihood. In some cases such as in the villages of the Mendalam Sub-watershed, Kapuas Hulu (Roslinda 2010), the communities believe that excessive use of forest will cause damage and catastrophic disaster. This social benefit of tembawang is actually the major reason for tembawang existence and sustained management.

The unexplored potency of tembawang is its ability to sequester and sink carbon. Based on Astiani and Ripin (2016), the tembawang sinks a large amount of above ground carbon especially the one found within mixed fruit garden patches reaching 300 ton/ha. Another potency that has not been explored is the use of tembawang as a natural laboratory for education and research. Many researchers have come to the site to conduct research. Till now, there is no charge at all for entering the site as long as they have permission from the local government. If every activity of research pays a certain amount of money as a fee, then there will be some amounts of fund can be used to preserve the existence of tembawang.

Tembawang ecosystem in Ampar Subvillage has significant role economically, socially, and ecologically. Therefore, any efforts of tembawang management should accommodate its role in avoiding negative externalities. Results of the calculation of the total value of tembawang potential benefits show that utilization of Tembawang Ampar, so far, has been done without disturbing existing tembawang ecosystems. Public awareness of the value and importance of tembawang is the crucial factor for careful maintenance of tembawang ecosystem. There are some issues that should be anticipated for the sustainability of tembawang ecosystem. The need for land conversion of secondary forest (including tembawang) into plantation (palm and rubber plantation) and mining is very high. Based on the interviews with communities and relevant stakeholders, it can be found that total area of palm plantation in Sanggau District tends to increase, because, economically, the plantation gives more promising prosperity than tembawang. This should be a concern of all parties because if economy burden continues to increase, while the alternative sources of income are limited, it is possible that the conversion of tembawang into plantation would be done extensively in the future. If this happens, then all the values of the tembawang ecosystem will be lost.

In conclusion, the benefits of tembawang ecosystem in Tembawang Ampar consist of direct benefits, indirect benefit, and option benefit of biodiversity values. Total potential economic value of Tembawang Ampar is $263,837,082$ year $^{-1}$, which is equivalent to IDR $36,900,291$ year $^{-1} \mathrm{ha}^{-1}$. It is IDR 33,545,791 year ${ }^{-1} \mathrm{ha}^{-1}$ from direct use value, IDR 3,072,738 year ${ }^{-1} \mathrm{ha}^{-1}$ from indirect use value, and IDR 281,762 year ${ }^{-1} \mathrm{ha}^{-1}$ from option value. The economic value of tembawang ecosystem was higher than the real benefit felt by the society. It was derived from an ecosystem, such as forest ecosystem. Forests have long been recognized as the main ecological construction and restoration means for their multiple ecosystem services (Deal et al. 2012). To optimize tembawang ecosystem management, there is a potential benefit that can be developed, i.e., benefit as carbon sequestering agent and sinker and a natural laboratory for education and research. In formulating strategies for optimal tembawang ecosystem management, significant consideration on research result on total economic value of tembawang ecosystems along with some issues that need to be anticipated including tembawang benefits (carbon sequestration and sink; natural laboratory) and the need of government's attention should be done to maintain the existence of tembawang as a landscape having rich in biodiversity and benefits.

\section{ACKNOWLEDGEMENTS}

We thank people of Ampar Subvillage for their contribution as respondents and key informants.

\section{REFERENCES}

Astiani D, Ripin. 2016. The roles of community fruit garden (tembawang) on maintaining forest structure, diversity and standing biomass allocation: an alternative effort on reducing carbon emission. Biodiversitas 17:359-365

Barbier EB, Acreman MC, Knowler D. 1997. Economic Valuation of Wetlands: A Guide for Policy Makers and Planners. Ramsar Convention Bureau, Gland, Switzerland.

Darusman D. 2012. Forestry for Sustainable Indonesia. IPB Press, Bogor. 
De Groot RS, Wilson M, Boumans R. 2002. A typology for the description, classification, and valuation of ecosystem services, goods and services. In: The dynamics and value of ecosystem services: Integrating economic and ecological perspectives. Special issue of Ecol Econ 41 (3): 393-408.

Deal RL, Cochran B, LaRocco G. 2012. Bundling of ecosystem services to increase forestland value and enhance sustainable forest management. For Pol Econ 17 (1): 69-76.

Directorate of Drinking Water Development cq. Cipta Karya. 2006. Water Consumption in Household. Cipta Karya, Jakarta. [Indonesian]

Fauzi A. 2004. Economy of Natural resources and Environments. Jakarta: Gramedia Pustaka Utama. [Indonesian].

Harahap N. 2010. Economic valuation of mangrove ecosystem and its application in coastal area planning. Yogyakarta: Graha Ilmu.

Hartwick JM, Olliver ND. 1998. The Economics of Natural Resources Use. Massachusetts: Addison - Wesley Educational Publisher Inc.

Kildow JT, Guo J. 2014. The gap between science and policy: Assessing the use of nonmarket valuation in Estuarine management. Working Paper http://citeseerx.ist.psu.edu/viewdoc/download?doi=10.1.1.671.5328\& rep=rep1\&type= pdf. [2 Mei 2015].

Kumar M, Kumar P. 2008. Valuation of the ecosystem services: A psycho-cultural perspective. Ecol Econ 64 (4): 808-819.

Malik A. Fensholt R, Mertz O. 2015. Economic valuation of mangroves for comparison with commercial aquaculture in South Sulawesi, Indonesia. Forest 6: 3028-3044.

Munasinghe M. (ed). 1993. Environmental Economics and Natural Resource Management. World Bank and CIDIE, Washington DC. USA.

Napitupulu L, Trinidad AC, Titaningtyas. 2012. The worth of coastal ecosystems in the Coral Triangle. In: Proceedings of the 12th International Coral Reef Symposium; Cairns, Australia, 9-13 July 2012.

PDAM. 2011 .Water distribution in Sanggau district. PDAM, Sanggau [Indonesian]

Pearce D, Moran D. 1994. The Economic Value of Biodiversity. IUCN \& Earthscan Publication Ltd., London.
Pemdes Cempedak. 2014. Cempedak Village Monograph in 2014. Cempedak Village Government, Sanggau. [Indonesian]

Regulation of the Minister of Trade of the Republic of Indonesia Number 92/M-Dag/Per/10/2015 on Determination of export benchmark prices on agricultural and forestry products subject to export duties. [Indonesian]

Rachmansyah Y, Maryono J. 2010. The important of economic valuation for sustainable management of conservation area. Prestasi 6 (2): 100110. [Indonesian]

Ripin. 2014. Diversity and Potency of Vegetation Species in Ampar Tembawang of Cempedak Village, Tayan Hilir Sub-district, Sanggau District. [Hon. Thesis]. Faculty of Forestry, University of Tanjungpura. Pontianak. [Indonesian]

Roslinda E, Ekyastuti W, Kartikawati SM. 2017. Social capital of community forest management on Nusapati Village Mempawah District, West Kalimantan, Indonesia. Biodiversitas 18 (2): 558-564.

Roslinda E, Yuliantini. 2014. The economic value of hydrological services in Mendalam sub-watershed, Kapuas Hulu Regency, West Kalimantan, Indonesia. Indonesian J For Res 1: 1-8.

Roslinda E. 2002. The economic value of Gunung Walat Educational Forest and its Contribution to the Surrounding Community. [Thesis]. Bogor Agricultural University, Bogor [Indonesian]

Roslinda E. 2013. Management policy options of Danau Sentarum National Park West Kalimantan Province. [Dissertation]. Bogor Agricultural University, Bogor [Indonesian]

Roslinda E. 2016. Dayak Desa forest land use system as social capital to acquire management rights in West Kalimantan, Indonesia. Biodiversitas 17 (1): 177-184

Siregar AF. 2012. Economic valuation and conservation strategic analysis of mangrove forest in Kubu Raya District. [Thesis]. Postgraduate Programme Forestry Science, Bogor Agricultural University. Bogor [Indonesian]

Zuhud EAM, Kartikawati SM, Roslinda E, Damayanti EK, Yahya AF, Metananda AA. 2015. Traditional Forest-Related Knowledge for Ecosystem Services in ASEAN Countries (Case Study of Sundanese Ethnic in Sukabumi District of WestJava Province, Indonesia). Presented on Terk Workshop, Kuala Lumpur 2-4 February 2015. 